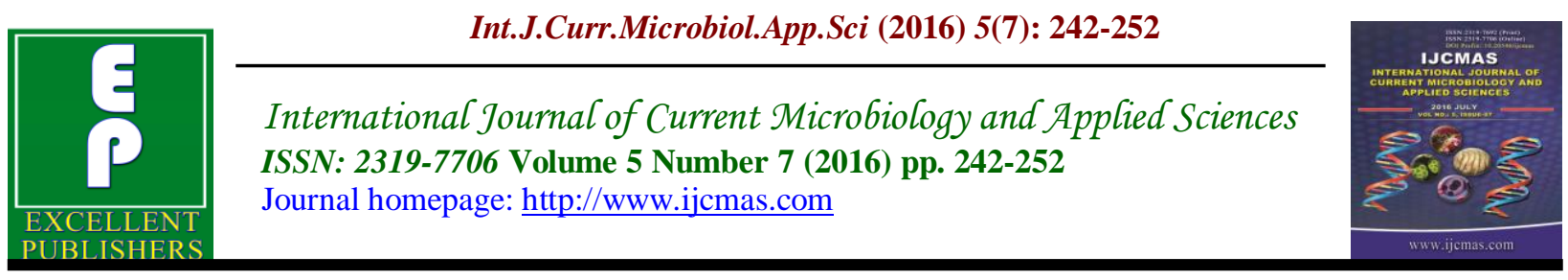

Original Research Article

http://dx.doi.org/10.20546/ijcmas.2016.507.025

\title{
Enrichment of Biogas Manures with Beneficial Microorganisms
}

\author{
Y. Kavya ${ }^{1 *}$, A. Vijaya Gopal ${ }^{1}$, R. Subhash Reddy ${ }^{1}$ and M. Sreedhar ${ }^{2}$ \\ ${ }^{1}$ Department of Agricultural Microbiology and Bio energy, College of Agriculture, \\ Acharya N. G. Ranga Agricultural University, Rajendranagar, Hyderabad-500030, India \\ ${ }^{2}$ Quality Control Laboratory, Acharya N. G. Ranga Agricultural University, Rajendranagar, \\ Hyderabad-500030, India \\ *Corresponding author
}

\begin{tabular}{l}
\hline \\
\hline Ke y w o r d s \\
Cow dung, \\
Press mud, \\
Poultry litter, \\
Kitchen wastes, \\
Maize stalks, \\
Enrichment, \\
Viability. \\
\hline Article Info \\
\hline Accepted: \\
12 June 2016 \\
Available Online: \\
10 July 2016
\end{tabular}

A B S T R A C T

The beneficial microorganisms used in the present study (Rhizobium, Pseudomonas, Azotobacter, Azospirillum) were collected from the department of Agricultural Microbiology, College of Agriculture, Rajendranagar, Hyderabad. All these four microorganisms were added to the biogas manure samples collected from biogas digesters set with six different substrates (cow dung, press mud, poultry litter, kitchen wastes, maize stalks and fruit wastes) after the gas production stopped. The beneficial microorganisms viability in the enriched biogas manures was monitored upto the end of tenth week and the increase in population was observed in all the biogas manures samples indicating that the biogas manure samples from different substrates support the beneficial microorganisms population for atleast 3-4 weeks duration.

\section{Introduction}

Organic manures in agriculture add much needed organic matter and minerals to the soil. The important manures used in organic farming are compost, vermicompost, biogas spent slurry, green manures and liquid organic manures like panchagavya, jeevamruth, etc. The beneficial effects of organic manures in agricultural production and soil fertility are known from many decades, but they are inadequate in nutrient supply and low in nutrient concentrations. The total nutrients recycled from organic matter decomposition are much less than the amount of nutrients utilized by the crop plants. This necessitates the enrichment of manures with beneficial microbial inoculants like free living nitrogen fixers, phosphate solubilizers etc. to improve the nutritional status of the manures. The enrichment of manures with beneficial microbial cultures results not only in improvement of nutritive value but also in higher growth and yield of crops. The microbial enrichment of organic manures will further contribute to the enhancement of phosphate solubilisation and nitrogen 
fixation (Hema et al. 2012). Hence, the present investigation was also aimed at enrichment of biogas manure with beneficial micro organisms.

\section{Materials and methods}

\section{Collection of biogas slurry}

Biogas slurry samples used in the present study were collected from biogas unit set in the lab scale with six treatments and three replication in the dept of Agricultural Microbiology and BioEnergy, College of Agriculture, Rajendranagar, Hyderabad. The six treatments include $\mathrm{T}_{1} 250 \mathrm{~g}$ cow dung + $500 \mathrm{~g}$ press mud $+1500 \mathrm{ml}$ water $(1: 2: 6), \mathrm{T}_{2}$ $250 \mathrm{~g}$ cow dung $+500 \mathrm{~g}$ poultry litter + $1500 \mathrm{ml}$ water (1:2:6), $\mathrm{T}_{3} 250 \mathrm{~g}$ cow dung + $500 \mathrm{~g}$ kitchen waste $+1500 \mathrm{ml}$ water (1:2:6), $\mathrm{T}_{4} 250 \mathrm{~g}$ cow dung $+500 \mathrm{~g}$ maize stalks $+1500 \mathrm{ml}$ water $(1: 2: 6)$, in $\mathrm{T}_{5} 250 \mathrm{~g}$ cow dung $+500 \mathrm{~g}$ fruit waste $+1500 \mathrm{ml}$ water (1:2:6) and $\mathrm{T}_{6} 750 \mathrm{~g}$ cow dung + $1500 \mathrm{ml}$ water (3:6). Biogas slurry samples were collected and dried under sun to 50 per cent moisture.

\section{Microbial Analysis of Biogas slurry manure}

The dried biogas slurry collected from different treatments was analysed for the presence of microorganisms i.e., Rhizobium, Azotobacter, Azospirillum, Pseudomonas were determined by serial dilution and plating on selective media as mentioned above. Replicates of the inoculated agar plates were incubated for 2 days at $37^{0} \mathrm{C}$ for Rhizobium and Pseudomonas, 7 days for Azotobacter and Azospirillum after which the counts were taken.

Viability of added beneficial microbes in Biogas slurry manure

\section{Collection of Beneficial micro organisms}

Beneficial microorganisms Rhizobium,
Pseudomonas, Azotobacter, Azospirillum cultures from the Agricultural Microbiology Department, College of Agriculture, Rajendranagar, were used in the experiment.

\section{Enrichment of Biogas slurry}

The dried biogas slurry samples collected from different treatments after drying were enriched with 4 types of biofertilizers viz: Rhizobium, Azotobacter, Azospirillum and Pseudomonas individually.

\section{Microbial Analysis of Biogas slurry} Enriched with Beneficial Microorganisms

Viable population of Rhizobium, Pseudomonas Azotobacter, Azospirillum were analyzed by the standard serial dilution plate count method (Vlassak et al., 1992) at weekly interval in the first month and monthly interval from the second month by using different media viz: Yeast Extract Mannitol Agar with Congo Red for Rhizobium, Kings-B for Pseudomonas (King et al. 1954), Azotobacter medium for Azotobacter spp., Potato infusion agar medium for Azospirillum spp., and plates were incubated at $28 \pm 2{ }^{\circ} \mathrm{C}$ in an incubator in triplicates. The microbial colonies appearing after the stipulated time period of incubation were counted as Colony forming units (CFU) $\mathrm{g}^{-1}$ fresh weight of the sample. The microbial populations were expressed as number of colony forming units per gram.

\section{Results and Discussion}

\section{Population of beneficial bacteria present in the biogas manures before enrichment}

The population of Rhizobium in the biogas manure samples (50 per cent moisture) was significantly more in $\mathrm{T}_{1}$ (Cow dung + Press mud) $46.0 \times 10^{3}$ CFU g ${ }^{-1}$ compared to $\mathrm{T}_{6}$

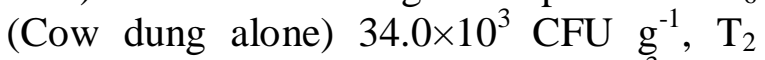
(Cow dung + Poultry litter) $32.0 \times 10^{3} \mathrm{CFU}$ 
$\mathrm{g}^{-1}, \mathrm{~T}_{3}$ (Cow dung + Kitchen waste) $6.1 \times 10^{3}$ $\mathrm{CFU} \mathrm{g}^{-1}, \mathrm{~T}_{5}$ (Cow dung + Fruit waste) $5.1 \times 10^{3} \mathrm{CFU} \mathrm{g}^{-1}$ and less in $\mathrm{T}_{4}$ (Cow dung + Maize stalks) $3.1 \times 10^{3} \mathrm{CFU} \mathrm{g}^{-1}$ (Table 3.1).

The population of Pseudomonas in the biogas manure samples $(50$ per cent moisture) was significantly more in $\mathrm{T}_{6}$ (Cow dung alone) $46.0 \times 10^{3} \mathrm{CFU} \mathrm{g}^{-1}$ compared to $\mathrm{T}_{2}$ (Cow dung + Poultry litter) $44.0 \times 10^{3}$ CFU g ${ }^{-1}, \mathrm{~T}_{1}$ (Cow dung + Press mud) $40.0 \times 10^{3} \mathrm{CFU} \mathrm{g}^{-1}, \mathrm{~T}_{3}$ (Cow dung + Kitchen

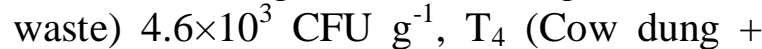
Maize stalks) $4.0 \times 10^{3} \mathrm{CFU} \mathrm{g}^{-1}$ and less in $\mathrm{T}_{5}$ (Cow dung + Fruit waste ) $3.0 \times 10^{3} \mathrm{CFU} \mathrm{g}^{-1}$ (Table 3.1).

The population of Azotobacter in the biogas manure samples (50 per cent moisture) was significantly more in $\mathrm{T}_{2}$ (Cow dung + Poultry litter) and $\mathrm{T}_{6}$ (Cow dung alone) $42.0 \times 10^{3} \mathrm{CFU} \mathrm{g}{ }^{-1}$ compared to $\mathrm{T}_{1}$ (Cow dung + Press mud) $12.0 \times 10^{3} \mathrm{CFU} \mathrm{g}{ }^{-1}, \mathrm{~T}_{3}$ (Cow dung + Kitchen waste) $4.6 \times 10^{3}$ CFU $\mathrm{g}^{-1}, \mathrm{~T}_{5}$ (Cow dung + Fruit waste ) $3.1 \times 10^{3}$ CFU g ${ }^{-1}$ and less in $\mathrm{T}_{4}$ (Cow dung + Maize stalks) $2.0 \times 10^{3} \mathrm{CFU} \mathrm{g}^{-1}$ (Table 3.1).

The population of Azospirillum in the biogas manure samples (50 per cent moisture) was significantly more in $\mathrm{T}_{6}$ (Cow dung alone) $24.0 \times 10^{3} \mathrm{CFU} \mathrm{g}{ }^{-1}$ compared to $\mathrm{T}_{1}$ (Cow dung + Press mud) $20.0 \times 10^{3} \mathrm{CFU} \mathrm{g}{ }^{-1}, \mathrm{~T}_{3}$ (Cow dung + Kitchen waste) $18.0 \times 10^{3} \mathrm{CFU}$ $\mathrm{g}^{-1}, \mathrm{~T}_{2}$ (Cow dung + Poultry litter) $12.0 \times 10^{3}$ $\mathrm{CFU} \mathrm{g}, \mathrm{T}_{5}$ (Cow dung + Fruit waste) $2.8 \times 10^{3} \mathrm{CFU} \mathrm{g}^{-1}$ and less in $\mathrm{T}_{4}$ (Cow dung + Maize stalks) $2.2 \times 10^{3} \mathrm{CFU} \mathrm{g}^{-1}$ (Table 3.1).

Hema et al. (2012) studied the influence of microbial enrichment on microbial population and nutrient status of organic manures. Microbial population in the slurry before enrichment was $80.5 \times 10^{5}$ bacteria, $124 \times 10^{3}$ fungi, $12 \times 10^{2}$ actinomycetes, $15.3 \times 10^{3}$ phosphate solubilise micro organisms and $20.2 \times 10^{3}$ free living nitrogen fixers.

Viability of the beneficial microorganisms inoculated individually into the biogas manure samples

Population of Rhizobium after the enrichment

The population of Rhizobium in the Yeast Extract Mannitol (YEM) broth was $3.1 \times 10^{9}$ CFU ml ${ }^{-1}$ (Table 3.2).

After the enrichment of the biogas manures with YEM broth, the population of Rhizobium on the first day was significantly more in $\mathrm{T}_{6}$ (Cow dung alone) $4.8 \times 10^{9} \mathrm{CFU}$ $\mathrm{g}^{-1}$ compared to $\mathrm{T}_{1}$ (Cow dung + Press mud) $3.2 \times 10^{9} \mathrm{CFU} \mathrm{g}{ }^{-1}, \mathrm{~T}_{2}$ (Cow dung + Poultry litter) $2.8 \times 10^{9} \mathrm{CFU} \mathrm{g^{-1 }}, \mathrm{T}_{3}$ (Cow dung + Kitchen waste) $1.0 \times 10^{9} \mathrm{CFU} \mathrm{g}^{-1}, \mathrm{~T}_{5}$ (Cow dung + Fruit waste ) $0.9 \times 10^{9} \mathrm{CFU} \mathrm{g}^{-1}$ and less in $\mathrm{T}_{4}$ (Cow dung + Maize stalks) $0.8 \times 10^{9} \mathrm{CFU} \mathrm{g}^{-1}$ (Table 3.3).

There was an increase in the population of Rhizobium in all the six treatments until the end of fourth week. The rate of multiplication was significantly more in $\mathrm{T}_{6}$ (Cow dung alone) $1.2 \times 10^{9} \mathrm{CFU} \mathrm{g}^{-1}\left(4.8 \times 10^{9}\right.$ $\mathrm{CFU} \mathrm{^{-1 }}$, on the first day to $6.1 \times 10^{9} \mathrm{CFU} \mathrm{g}^{-1}$, at the end of fourth week) and less in $\mathrm{T}_{4}$ (Cow dung + Maize stalks) $0.6 \times 10^{9} \mathrm{CFU} \mathrm{g}^{-1}$ $\left(0.8 \times 10^{9} \mathrm{CFU} \mathrm{g}^{-1}\right.$, on the first day to $1.6 \times 10^{9}$ CFU g ${ }^{-1}$, at the end of fourth week). The decrease in population was observed after fourth week and significantly more reduction in the population was observed in $\mathrm{T}_{6}$ (Cow dung alone) $6.1 \times 10^{9} \mathrm{CFU} \mathrm{g}^{-1}$ at the end of fourth week to $3.0 \times 10^{8} \mathrm{CFU} \mathrm{g}^{-1}$ at the end of sixth week and less reduction in population was observed in $\mathrm{T}_{5}$ (Cow dung + Fruit waste) $1.9 \times 10^{9} \mathrm{CFU} \mathrm{g}{ }^{-1}$ to $0.8 \times 10^{8}$ CFU g ${ }^{-1}$ (Table 3.3). Finally the viability was significantly more in $\mathrm{T}_{5}$ (Cow dung + 
Fruit waste) $0.9 \times 10^{9} \mathrm{CFU} \mathrm{g}^{-1}$, on the first day to $0.5 \times 10^{7} \mathrm{CFU} \mathrm{g}^{-1}$ at the end of tenth week and comparatively less viability was observed in $\mathrm{T}_{2}$ (Cow dung + Poultry litter) $2.8 \times 10^{9} \mathrm{CFU} \mathrm{g}^{-1}$ on the first day and $0.8 \times 10^{7}$ $\mathrm{CFU} \mathrm{g}^{-1}$ at the end of tenth week (Table 3.3).

\section{Population of Pseudomonas after the enrichment}

The population of Pseudomonas in Kings B broth was $3.0 \times 10^{9} \mathrm{CFU} \mathrm{ml}^{-1}$ (Table 3.2).

After the enrichment of the biogas manures with King's B broth, the population of Pseudomonas on the first day was significantly more in $\mathrm{T}_{6}$ (Cow dung alone) $3.2 \times 10^{9} \mathrm{CFU} \mathrm{g}^{-1}$ compared to $\mathrm{T}_{2}$ (Cow dung + Poultry litter) $2.4 \times 10^{9} \mathrm{CFU} \mathrm{g}{ }^{-1}, \mathrm{~T}_{1}$ (Cow dung + Press mud) $1.8 \times 10^{9} \mathrm{CFU} \mathrm{g}{ }^{-1}, \mathrm{~T}_{4}$ (Cow dung + Maize stalks) $1.6 \times 10^{9} \mathrm{CFU} \mathrm{g}^{-}$ ${ }^{1}, \mathrm{~T}_{5}$ (Cow dung + Fruit waste ) $1.1 \times 10^{9}$ CFU g ${ }^{-1}$ and less in $\mathrm{T}_{3}$ (Cow dung + Kitchen waste) $1.0 \times 10^{9} \mathrm{CFU} \mathrm{g}^{-1}$ (Table 3.4).

There was an increase in the population of Pseudomonas in all the six treatments until the end of fourth week. The rate of multiplication was significantly more in $\mathrm{T}_{3}$ (Cow dung + Kitchen waste) $2.6 \times 10^{9} \mathrm{CFU}$ $\mathrm{g}^{-1}\left(1.0 \times 10^{9} \mathrm{CFU} \mathrm{g} \mathrm{g}^{-1}\right.$ on the first day to $3.6 \times 10^{9} \mathrm{CFU} \mathrm{g}^{-1}$ at the end of fourth week) and less in $\mathrm{T}_{2}$ (Cow dung + Poultry litter) $1.6 \times 10^{9} \mathrm{CFU} \mathrm{g}^{-1}\left(2.4 \times 10^{9}\right.$ on the first day to $4.0 \times 10^{9}$ at the end of fourth week). The decrease in population was observed after fourth week and significantly more reduction in the population was observed in $\mathrm{T}_{1}$ (Cow dung + Press mud) $3.7 \times 10^{9} \mathrm{CFU} \mathrm{g}^{-}$ 1 at the end of fourth week to $2.1 \times 10^{8} \mathrm{CFU}$ $\mathrm{g}^{-1}$ at the end of sixth week and less reduction was observed in $\mathrm{T}_{2}$ (Cow dung + Poultry litter) $4.0 \times 10^{9} \mathrm{CFU} \mathrm{g}^{-1}$ at the end of fourth week to $2.5 \times 10^{8} \mathrm{CFU} \mathrm{g}^{-1}$ at the end of sixth week (Table 3.4). Finally the viability was significantly more in $T_{3}$ (Cow dung +
Kitchen waste) $1.0 \times 10^{9} \mathrm{CFU} \mathrm{g}^{-1}$ on the first day to $2.0 \times 10^{7} \mathrm{CFU} \mathrm{g}{ }^{-1}$ at the end of tenth week and comparatively less viability was observed in $\mathrm{T}_{4}$ (Cow dung + Maize stalks) $1.6 \times 10^{9} \mathrm{CFU} \mathrm{g}^{-1}$ on the first day to $1.4 \times 10^{7}$ CFU $\mathrm{g}^{-1}$ at the end of tenth week (Table 3.4).

Population of Azotobacter after the enrichment

The population of Azotobacter in Azotobacter glucose broth was $2.6 \times 10^{9} \mathrm{CFU}$ $\mathrm{ml}^{-1}$ (Table 3.2).

After the enrichment of the biogas manures with Azotobacter glucose broth, the population of Azotobacter on the first day was significantly more in $\mathrm{T}_{6}$ (Cow dung alone) $2.8 \times 10^{9} \mathrm{CFU} \mathrm{g}{ }^{-1}$ compared to $\mathrm{T}_{1}$ (Cow dung + Press mud) $2.2 \times 10^{9} \mathrm{CFU} \mathrm{g}^{-1}$, $\mathrm{T}_{2}$ (Cow dung + Poultry litter) $2.0 \times 10^{9} \mathrm{CFU}$ $\mathrm{g}^{-1}, \mathrm{~T}_{3}$ (Cow dung + Kitchen waste) $1.7 \times 10^{9}$ CFU g ${ }^{-1}, \mathrm{~T}_{5}$ (Cow dung + Fruit waste ) $1.2 \times 10^{9} \mathrm{CFU} \mathrm{g}^{-1}$ and less in $\mathrm{T}_{4}$ (Cow dung + Maize stalks) $1.0 \times 10^{9} \mathrm{CFU} \mathrm{g}^{-1}$ (Table 3.5).

There was an increase in the population of Azotobacter in all the six treatments until the end of third week. The rate of multiplication was significantly more in $\mathrm{T}_{1}$ (Cow dung + Press mud) $1.6 \times 10^{9} \mathrm{CFU} \mathrm{g}^{-1}\left(2.2 \times 10^{9} \mathrm{CFU}\right.$ $\mathrm{g}^{-1}$ on the first day to $3.8 \times 10^{9} \mathrm{CFU} \mathrm{g}{ }^{-1}$ at the end of third week) and less in $\mathrm{T}_{5}$ (Cow dung + Fruit waste) $1.2 \times 10^{9} \mathrm{CFU} \mathrm{g}^{-1}\left(1.2 \times 10^{9}\right.$ $\mathrm{CFU} \mathrm{g}{ }^{-1}$ on the first day to $1.4 \times 10^{9} \mathrm{CFU} \mathrm{g}^{-1}$ at the end of third week). The decrease in population was observed after third week and significantly more reduction in the population was observed in $\mathrm{T}_{4}$ (Cow dung + Maize stalks) $2.2 \times 10^{9} \mathrm{CFU} \mathrm{g}^{-1}$ at the end of third week to $2.5 \times 10^{8} \mathrm{CFU} \mathrm{g}^{-1}$ at the end of fourth week and less reduction was in $\mathrm{T}_{1}$ (Cow dung + Press mud) $3.8 \times 10^{9} \mathrm{CFU} \mathrm{g}^{-1}$ to $4.4 \times 10^{9} \mathrm{CFU} \mathrm{g}^{-1}$ (Table 3.5). 
Table.1 Population of beneficial bacteria present in the biogas manures before enrichment with beneficial microorganisms.

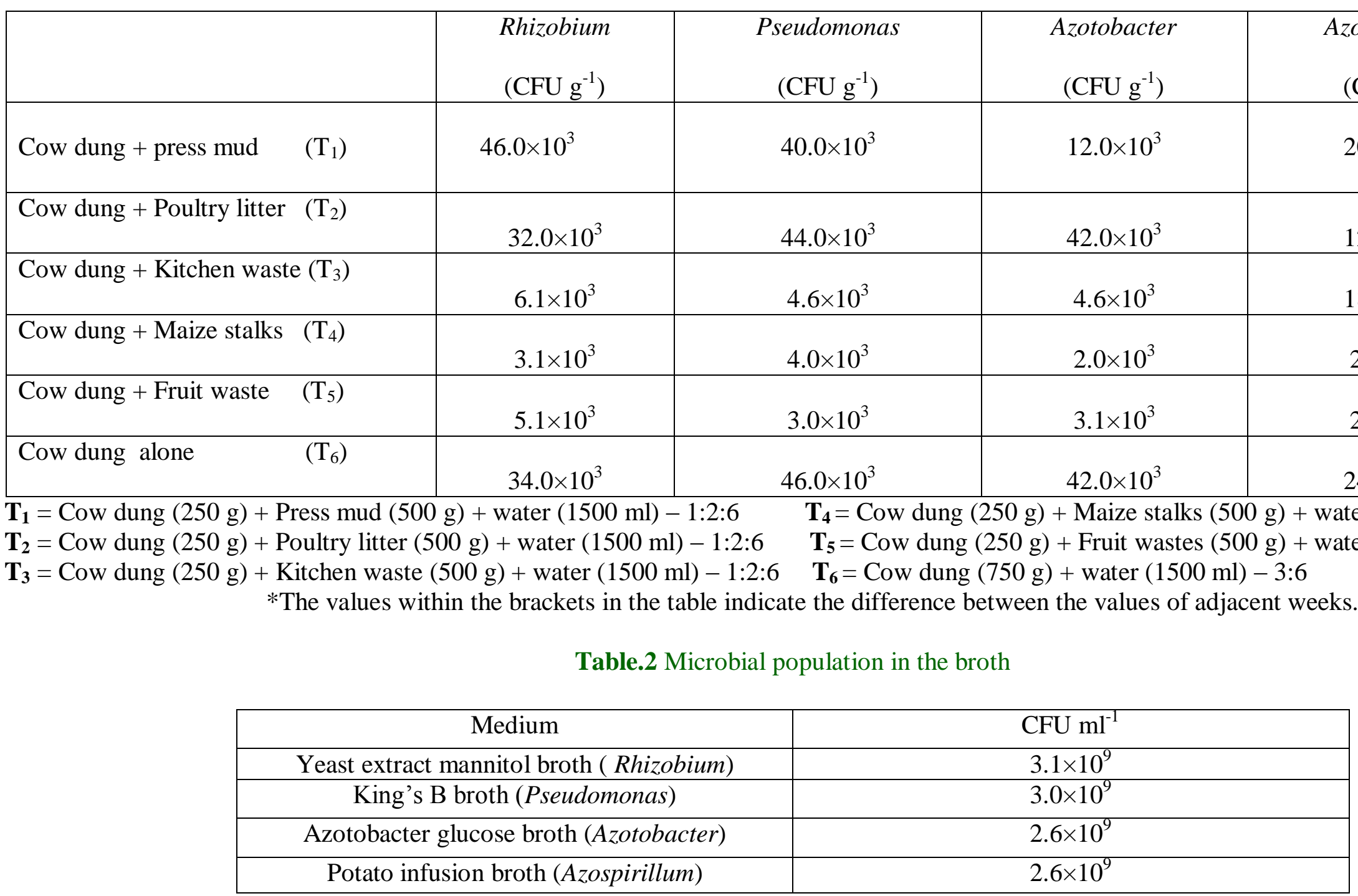


Table.3 Population of Rhizobium present in the biogas manures after the enrichment.

\begin{tabular}{|c|c|c|c|c|c|c|c|c|}
\hline & $\begin{array}{c}\text { Initial } \\
\left(\times 10^{9} \mathbf{C F}\right. \\
\left.\mathbf{U}^{-1} \mathbf{g}\right)\end{array}$ & $\begin{array}{l}\text { At the end of } \\
\text { first week } \\
(\mathbf{7 t h} \text { day }) \\
\left(\times \mathbf{1 0}^{9} \mathrm{CFU} \mathrm{^{-1 } )}\right.\end{array}$ & $\begin{array}{c}\text { At the end of } \\
\text { second week } \\
(14 \text { th day }) \\
\left(\times \mathbf{1 0}^{9} \mathrm{CFU} \mathrm{g^{-1 } )}\right.\end{array}$ & $\begin{array}{l}\text { At the end of } \\
\text { third week } \\
(21 \text { st day }) \\
\left(\times \mathbf{1 0}^{9} \mathrm{CFU} \mathbf{g}^{-1}\right)\end{array}$ & $\begin{array}{c}\text { At the end of } \\
\text { fourth week } \\
(28 \text { th day }) \\
\left(\times \mathbf{1 0}^{9} \mathrm{CFU} \mathrm{g^{-1 } )}\right.\end{array}$ & $\begin{array}{l}\text { At the end of } \\
\text { sixth week } \\
(42 n d \text { day }) \\
\left(\times \mathbf{1 0}^{8} \mathrm{CFUg}^{-1}\right)\end{array}$ & $\begin{array}{c}\text { At the end of } \\
\text { eighth week } \\
(56 \text { th day) } \\
\left(\times 10^{7} \mathrm{CFUg}^{-1}\right)\end{array}$ & $\begin{array}{l}\text { At the end of } \\
\text { tenth week } \\
\text { (70thday) } \\
\left(\times 10^{7} \text { CFUg }{ }^{-1}\right)\end{array}$ \\
\hline $\mathbf{T}_{1}$ & 3.06 & $3.20(0.14)$ & $3.40(0.20)$ & $3.66(0.26)$ & $4.00(0.34)$ & $1.93(3.80)$ & $3.00(1.60)$ & $2.16(0.84)$ \\
\hline $\mathbf{T}_{2}$ & 2.86 & $3.13(0.27)$ & $3.26(0.13)$ & $3.53(0.30)$ & $3.66(0.13)$ & $1.43(3.51)$ & $2.03(1.22)$ & $0.86(1.17)$ \\
\hline $\mathbf{T}_{3}$ & 1.00 & $1.33(0.33)$ & $1.46(0.13)$ & $1.66(0.20)$ & $1.93(0.27)$ & $0.80(1.85)$ & $1.03(0.60)$ & $0.36(0.67)$ \\
\hline $\mathbf{T}_{5}$ & 0.93 & $1.26(0.33)$ & $1.53(0.27)$ & $1.66(0.13)$ & $1.93(0.27)$ & $0.86(1.84)$ & $1.13(0.74)$ & $0.46(0.67)$ \\
\hline $\mathbf{T}_{6}$ & 4.86 & $5.13(0.27)$ & $5.33(0.20)$ & $5.66(0.33)$ & $6.06(0.40)$ & $3.03(5.75)$ & $4.43(2.58)$ & $3.26(1.17)$ \\
\hline S.E(m) & 0.077 & 0.077 & 0.077 & 0.065 & 0.077 & 0.038 & 0.045 & 0.038 \\
\hline $\begin{array}{c}\text { CD } \\
\mathbf{P}=0.05\end{array}$ & 0.240 & 0.240 & 0.240 & 0.203 & 0.240 & 0.120 & 0.141 & 0.120 \\
\hline
\end{tabular}

$\mathbf{T}_{1}=$ Cow dung $(250 \mathrm{~g})+$ Press mud $(500 \mathrm{~g})+$ water $(1500 \mathrm{ml})-1: 2: 6 \quad \mathbf{T}_{4}=$ Cow dung $(250 \mathrm{~g})+$ Maize stalks $(500 \mathrm{~g})+$ water $(1500 \mathrm{ml})-1: 2: 6$

$\mathbf{T}_{2}=$ Cow dung $(250 \mathrm{~g})+$ Poultry litter $(500 \mathrm{~g})+$ water $(1500 \mathrm{ml})-1: 2: 6 \quad \mathbf{T}_{5}=$ Cow dung $(250 \mathrm{~g})+$ Fruit wastes $(500 \mathrm{~g})+$ water $(1500 \mathrm{ml})-1: 2: 6$ $\mathbf{T}_{3}=$ Cow dung $(250 \mathrm{~g})+$ Kitchen waste $(500 \mathrm{~g})+$ water $(1500 \mathrm{ml})-1: 2: 6 \quad \mathbf{T}_{\mathbf{6}}=$ Cow dung $(750 \mathrm{~g})+$ water $(1500 \mathrm{ml})-3: 6$

*The values within the brackets in the table indicate the difference between the values of adjacent weeks. 
Table.4 Population of Pseudomonas present in the biogas manures after the enrichment.

\begin{tabular}{|c|c|c|c|c|c|c|c|c|}
\hline & $\begin{array}{c}\text { Initial(x } \\
10^{9} \mathrm{CFU} \\
\left.\mathrm{g}^{-1}\right)\end{array}$ & $\begin{array}{c}\text { At the end of } \\
\text { first week } \\
\left(7^{\text {th }} \text { day }\right) \\
\left(\times \mathbf{1 0}^{9} \mathrm{CFU} \mathrm{g^{-1 } )}\right.\end{array}$ & $\begin{array}{c}\text { At the end of } \\
\text { second week } \\
(14 \text { th day }) \\
\left(\times 10^{9} \mathrm{CFUg}^{1}\right)\end{array}$ & 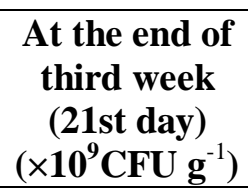 & 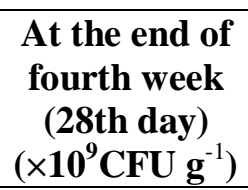 & 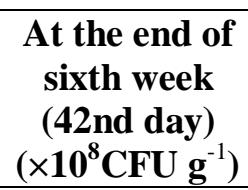 & 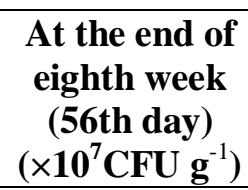 & $\begin{array}{c}\text { At the end of } \\
\text { tenth week } \\
(70 \text { th day }) \\
\left(\times 10^{7} \text { CFU g }{ }^{-1}\right)\end{array}$ \\
\hline $\mathbf{T}_{1}$ & 1.83 & $2.56(0.73)$ & $3.03(0.47)$ & $3.46(0.43)$ & $3.73(0.27)$ & $2.16(3.51)$ & $3.33(1.82)$ & $2.36(0.97)$ \\
\hline $\mathbf{T}_{2}$ & 2.36 & $2.86(0.50)$ & $3.13(0.27)$ & $3.63(0.50)$ & $4.03(0.40)$ & $2.56(3.77)$ & $3.56(2.20)$ & $3.06(0.50)$ \\
\hline $\mathbf{T}_{3}$ & 1.03 & $1.53(0.50)$ & $2.66(1.13)$ & $3.16(0.50)$ & $3.63(0.47)$ & $1.86(3.44)$ & $2.26(1.60)$ & $2.03(0.23)$ \\
\hline $\mathbf{T}_{4}$ & 1.56 & $2.03(0.47)$ & $2.76(0.73)$ & $3.03(0.27)$ & $3.36(0.33)$ & $1.26(3.23)$ & $2.03(1.05)$ & $1.43(0.60)$ \\
\hline $\mathbf{T}_{5}$ & 1.13 & $1.43(0.30)$ & $1.73(0.40)$ & $2.56(0.83)$ & $3.03(0.47)$ & $1.03(2.92)$ & $1.73(1.62)$ & $1.03(0.70)$ \\
\hline$T_{6}$ & 3.16 & $4.00(0.84)$ & $4.83(0.83)$ & $5.33(0.50)$ & $5.73(0.40)$ & $3.56(5.37)$ & $3.83(3.17)$ & $3.36(0.47)$ \\
\hline S.E(m) & 0.041 & 0.065 & 0.053 & 0.047 & 0.047 & 0.047 & 0.047 & 0.041 \\
\hline $\begin{array}{c}\mathbf{C D} \\
(\mathbf{P}=\mathbf{0 . 0 5})\end{array}$ & 0.127 & 0.203 & 0.164 & 0.147 & 0.147 & 0.147 & 0.147 & 0.127 \\
\hline
\end{tabular}

$\mathbf{T}_{\mathbf{1}}=$ Cow dung $(250 \mathrm{~g})+$ Press mud $(500 \mathrm{~g})+$ water $(1500 \mathrm{ml})-1: 2: 6 \quad \mathbf{T}_{\mathbf{4}}=$ Cow dung $(250 \mathrm{~g})+$ Maize stalks $(500 \mathrm{~g})+$ water+(1500 $\left.\mathrm{ml}\right)-1: 2: 6$ $\mathbf{T}_{2}=$ Cow dung $(250 \mathrm{~g})+$ Poultry litter $(500 \mathrm{~g})+$ water $(1500 \mathrm{ml})-1: 2: 6 \quad \mathbf{T}_{5}=$ Cow dung $(250 \mathrm{~g})+$ Fruit wastes $(500 \mathrm{~g})+$ water $(1500 \mathrm{ml})-1: 2: 6$ $\mathbf{T}_{3}=$ Cow dung $(250 \mathrm{~g})+$ Kitchen waste $(500 \mathrm{~g})+$ water $(1500 \mathrm{ml})-1: 2: 6 \quad \mathbf{T}_{6}=$ Cow dung $(750 \mathrm{~g})+$ water $(1500 \mathrm{ml})-3: 6$

$*$ The values within the brackets in the table indicate the difference between the values of adjacent weeks. 
Table.5 Population of Azotobacter present in the biogas manures after the enrichment.

\begin{tabular}{|c|c|c|c|c|c|c|c|c|}
\hline & $\begin{array}{c}\text { Initial } \\
\left(\times 10^{9} \mathrm{CFU}\right. \\
\left.\mathrm{g}^{-1}\right)\end{array}$ & $\begin{array}{l}\text { At the end of } \\
\text { first week } \\
\left(7^{\text {th }} \text { day }\right) \\
\left(\times 10^{9} \mathrm{CFU} \mathbf{g}^{-1}\right)\end{array}$ & $\begin{array}{l}\text { At the end of } \\
\text { second week } \\
\left(14^{\text {th }} \text { day }\right) \\
\left(\times \mathbf{1 0}^{9} \mathrm{CFU} \mathrm{^{-1 } )}\right.\end{array}$ & $\begin{array}{c}\text { At the end of } \\
\text { third week } \\
\left(21^{\text {st }} \text { day }\right) \\
\left(\times \mathbf{1 0}^{9} \mathrm{CFU} \mathrm{^{-1 } )}\right.\end{array}$ & 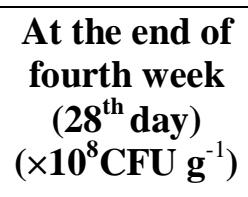 & $\begin{array}{l}\text { At the end of } \\
\text { sixth week } \\
\left(42^{\text {nd }} \text { day }\right) \\
\left(\times 10^{8} \mathrm{CFU} \mathrm{^{-1 } )}\right.\end{array}$ & $\begin{array}{l}\text { At the end of } \\
\text { eighth week } \\
\left(5^{\text {th }} \text { day }\right) \\
\left(\times 10^{7} \mathrm{CFU} \mathrm{g^{-1 }}\right)\end{array}$ & $\begin{array}{c}\text { At the end of } \\
\text { tenth week } \\
\left(\mathbf{7 0}^{\text {th }} \text { day }\right) \\
\left(\times 10^{6} \mathrm{CFU} \mathrm{^{-1 } )}\right.\end{array}$ \\
\hline $\mathbf{T}_{1}$ & 2.23 & $3.03(0.80)$ & $3.40(0.37)$ & $3.86(0.46)$ & $4.46(0.60)$ & $2.03(2.430$ & $3.13(1.71)$ & $3.16(2.80)$ \\
\hline $\mathbf{T}_{2}$ & 2.03 & $2.76(0.73)$ & $3.16(0.40)$ & $3.56(0.40)$ & $4.03(0.47)$ & $1.56(2.47)$ & $2.36(1.32)$ & $2.23(2.13)$ \\
\hline $\mathbf{T}_{3}$ & 1.66 & $2.13(0.47)$ & $2.66(0.53)$ & $3.03(0.37)$ & $3.63(0.60)$ & 1.3392.30) & $2.16(1.11)$ & $1.40(2.00)$ \\
\hline $\mathbf{T}_{4}$ & 1.03 & $1.43(0.40)$ & $2.03(0.60)$ & $2.23(0.20)$ & $2.56(0.33)$ & $1.03(1.53)$ & $2.26(0.80)$ & $1.13(2.14)$ \\
\hline $\mathbf{T}_{5}$ & 1.26 & $1.83(0.57)$ & $2.23(0.40)$ & $2.43(0.20)$ & $3.03(0.60)$ & $1.13(1.90)$ & $2.00(0.90)$ & $1.26(1.87)$ \\
\hline $\mathbf{T}_{6}$ & 2.83 & $3.56(0.73)$ & $4.03(0.47)$ & $4.23(0.20)$ & $4.83(0.60)$ & $3.03(1.80)$ & $2.76(2.75)$ & $4.06(2.35)$ \\
\hline S.E(m) & 0.047 & 0.041 & 0.038 & 0.033 & 0.033 & 0.047 & 0.045 & 0.051 \\
\hline $\begin{array}{c}\text { CD } \\
(P=0.05)\end{array}$ & 0.147 & 0.127 & 0.120 & 0.104 & 0.104 & 0.147 & 0.141 & 0.159 \\
\hline
\end{tabular}

$\mathbf{T}_{1}=$ Cow dung $(250 \mathrm{~g})+$ Press mud $(500 \mathrm{~g})+$ water $(1500 \mathrm{ml})-1: 2: 6 \quad \mathbf{T}_{\mathbf{4}}=$ Cow dung $(250 \mathrm{~g})+$ Maize stalks $(500 \mathrm{~g})+$ water $(1500 \mathrm{ml})-1: 2: 6$ $\mathbf{T}_{2}=$ Cow dung $(250 \mathrm{~g})+$ Poultry litter $(500 \mathrm{~g})+$ water $(1500 \mathrm{ml})-1: 2: 6 \mathbf{T}_{5}=$ Cow dung $(250 \mathrm{~g})+$ Fruit wastes $(500 \mathrm{~g})+$ water $(1500 \mathrm{ml})-1: 2: 6$ $\mathbf{T}_{3}=$ Cow dung $(250 \mathrm{~g})+$ Kitchen waste $(500 \mathrm{~g})+$ water $(1500 \mathrm{ml})-1: 2: 6 \mathbf{T}_{\mathbf{6}}=$ Cow dung $(750 \mathrm{~g})+$ water $(1500 \mathrm{ml})-3: 6$

$*$ The values within the brackets in the table indicate the difference between the values of adjacent weeks. 
Table.6 Population of Azospirillum present in the biogas manures after the enrichment.

\begin{tabular}{|c|c|c|c|c|c|c|c|c|}
\hline & $\begin{array}{c}\text { Initial } \\
\left(\times 10^{9} \mathbf{C F}\right. \\
\left.\mathbf{U ~ g}^{-1}\right)\end{array}$ & $\begin{array}{r}\text { At the end of } \\
\text { first week (7th } \\
\text { day) } \\
\left(\times 10^{9} \mathrm{CFU} \mathrm{\textrm {g } ^ { - 1 } )}\right.\end{array}$ & 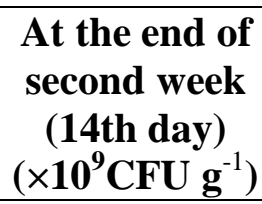 & 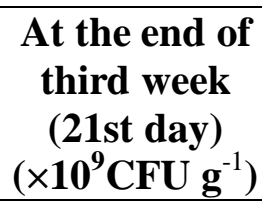 & 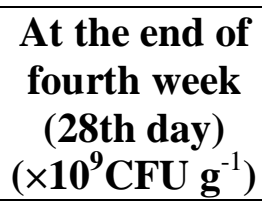 & 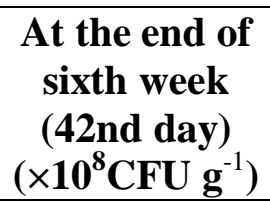 & $\begin{array}{l}\text { At the end of } \\
\text { eighth week } \\
(56 \text { thday }) \\
\left(\times 10^{7} \mathrm{CFU} \mathrm{g}^{-1}\right)\end{array}$ & 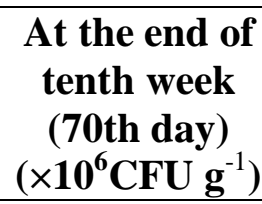 \\
\hline $\mathbf{T}_{1}$ & 2.36 & $2.76(0.40)$ & $3.23(0.47)$ & $3.40(0.17)$ & $3.63(0.23)$ & $2.36(3.39)$ & $1.66(2.10)$ & $3.03(1.35)$ \\
\hline$T_{2}$ & 2.03 & $2.60(0.57)$ & $2.83(0.23)$ & $3.03(0.20)$ & $3.36(0.33)$ & $2.03(3.15)$ & $1.16(1.91)$ & $2.76(0.88)$ \\
\hline $\mathbf{T}_{3}$ & 1.40 & $1.76(0.36)$ & $2.06(0.30)$ & $2.43(0.34)$ & $2.73(0.40)$ & $1.66(2.56)$ & $1.00(1.56)$ & $2.00(0.80)$ \\
\hline $\mathbf{T}_{4}$ & 1.03 & $1.16(0.13)$ & $1.56(0.60)$ & $1.83(0.27)$ & $2.16(0.33)$ & $2.03(1.95)$ & $1.63(1.86)$ & $1.03(1.52)$ \\
\hline $\mathbf{T}_{5}$ & 0.56 & $1.06(0.50)$ & $1.76(0.60)$ & $2.03(0.27)$ & $2.33(0.30)$ & $2.13(2.11)$ & $1.43(1.98)$ & $1.33(1.29)$ \\
\hline$T_{6}$ & 2.63 & $3.13(0.50)$ & $3.56(0.33)$ & $3.80(0.24)$ & $4.03(0.23)$ & $3.03(3.72)$ & $2.03(2.82)$ & $3.36(1.69)$ \\
\hline S.E(m) & 0.030 & 0.045 & 0.041 & 0.027 & 0.047 & 0.047 & 0.038 & 0.038 \\
\hline $\begin{array}{c}\text { CD } \\
\mathbf{P}=0.05\end{array}$ & 0.095 & 0.141 & 0.127 & 0.085 & 0.147 & 0.147 & 0.120 & 0.120 \\
\hline
\end{tabular}

$\mathbf{T}_{\mathbf{1}}=$ Cow dung $(250 \mathrm{~g})+$ Press mud $(500 \mathrm{~g})+$ water $(1500 \mathrm{ml})-1: 2: 6 \quad \mathbf{T}_{\mathbf{4}}=$ Cow dung $(250 \mathrm{~g})+$ Maize stalks $(500 \mathrm{~g})+$ water $(1500 \mathrm{ml})-1: 2: 6$

$\mathbf{T}_{2}=$ Cow dung $(250 \mathrm{~g})+$ Poultry litter $(500 \mathrm{~g})+$ water $(1500 \mathrm{ml})-1: 2: 6 \quad \mathbf{T}_{\mathbf{5}}=$ Cow dung $(250 \mathrm{~g})+$ Fruit wastes $(500 \mathrm{~g})+$ water $(1500 \mathrm{ml})-1: 2: 6$ $\mathbf{T}_{3}=$ Cow dung $(250 \mathrm{~g})+$ Kitchen waste $(500 \mathrm{~g})+$ water $(1500 \mathrm{ml})-1: 2: 6 \mathbf{T}_{\mathbf{6}}=$ Cow dung $(750 \mathrm{~g})+$ water $(1500 \mathrm{ml})-3: 6$

*The values within the brackets in the table indicate the difference between the values of adjacent weeks. 
Finally the viability was significantly more in $\mathrm{T}_{6}$ (Cow dung alone) $2.8 \times 10^{9} \mathrm{CFU} \mathrm{g}^{-1}$ on the first day to $4.1 \times 10^{6} \mathrm{CFU} \mathrm{g}^{-1}$ at the end of tenth week and comparitively less viability was observed in $\mathrm{T}_{3}$ (Cow dung + Kitchen waste) $1.7 \times 10^{9} \mathrm{CFU} \mathrm{g}^{-1}$ on the first day to $1.4 \times 10^{7} \mathrm{CFU} \mathrm{g}^{-1}$ at the end of tenth week (Table 3.5).

\section{Population of Azospirillum after the enrichment}

The population of Azospirillum in the potato infusion broth was $2.6 \times 10^{9} \mathrm{CFU} \mathrm{ml}^{-1}$ (Table $3.2)$.

After the enrichment of the dried biogas manures with potato infusion broth, the population of Azospirillum on the first day was significantly more in $\mathrm{T}_{6}$ (Cow dung alone) $2.6 \times 10^{9}$ CFU g ${ }^{-1}$ compared to $\mathrm{T}_{1}$ (Cow dung + Press mud) $2.4 \times 10^{9} \mathrm{CFU} \mathrm{g}^{-1}$, $\mathrm{T}_{2}$ (Cow dung + Poultry litter) $2.0 \times 10^{9} \mathrm{CFU}$ $\mathrm{g}^{-1}, \mathrm{~T}_{3}$ (Cow dung + Kitchen waste) $1.4 \times 10^{9}$ $\mathrm{CFU} \mathrm{g}{ }^{-1}, \mathrm{~T}_{4}$ (Cow dung + Maize stalks) $1.0 \times 10^{9} \mathrm{CFU} \mathrm{g}^{-1}$ and less in $\mathrm{T}_{5}$ (Cow dung + Fruit waste) $0.6 \times 10^{9} \mathrm{CFU} \mathrm{g}^{-1}$ (Table 3.6).

There was an increase in the population of Azospirillum in all the six treatments until the end of fourth week. The rate of multiplication was significantly more in $T_{5}$ (Cow dung + Fruit waste) $1.7 \times 10^{9} \mathrm{CFU} \mathrm{g}^{-1}$ $\left(0.6 \times 10^{9} \mathrm{CFU} \mathrm{g} \mathrm{g}^{-1}\right.$ on the first day to $2.3 \times 10^{9}$ $\mathrm{CFU} \mathrm{\textrm {g } ^ { - 1 }}$ at the end of fourth week) and less in $\mathrm{T}_{4}$ (Cow dung + Maize stalks) $1.1 \times 10^{9}$ $\mathrm{CFU} \mathrm{g}^{-1}\left(1.0 \times 10^{9} \mathrm{CFU} \mathrm{g}^{-1}\right.$ on the first day to $2.1 \times 10^{9} \mathrm{CFU} \mathrm{g}^{-1}$ at the end of fourth week). The decrease in population was observed after fourth week and significantly more reduction in the population was observed in $\mathrm{T}_{2}$ (Cow dung + Poultry litter) $3.4 \times 10^{9} \mathrm{CFU}$ $\mathrm{g}^{-1}$ at the end of fourth week to $2.0 \times 10^{8} \mathrm{CFU}$ $\mathrm{g}^{-1}$ at the end of sixth week and less reduction was observed in $\mathrm{T}_{4}$ (Cow dung + Maize stalks) $2.16 \times 10^{9} \mathrm{CFU} \mathrm{g}^{-1}$ to $2.03 \times 10^{8}$
CFU $\mathrm{g}^{-1}$ (Table 3.6). Finally the viability was significantly more in $\mathrm{T}_{5}$ (Cow dung + Fruit waste) $0.6 \times 10^{9} \mathrm{CFU} \mathrm{g}^{-1}$ on the first day to $1.3 \times 10^{6} \mathrm{CFU} \mathrm{g}^{-1}$ at the end of tenth week and comparatively less viability was observed in $\mathrm{T}_{4}$ (Cow dung + Maize stalks) $1.0 \times 10^{9} \mathrm{CFU} \mathrm{g}^{-1}$ on the first day to $1.0 \times 10^{6}$ $\mathrm{CFU} \mathrm{\textrm {g } ^ { - 1 }}$ at the end of tenth week (Table 3.6).

Shruthi et al. (2014) carried work on the survivability of Bacillus megatherium in different carrier materials for improved shelf life of biofertilizer. The microbial population was estimated once in 30 days upto 240 days of storage $\left(13.3 \times 10^{7} \mathrm{CFU} \mathrm{g}^{-1}\right.$ at 30 days and $2 \times 10^{7} \mathrm{CFU} \mathrm{g} \mathrm{g}^{-1}$ at 240 days). Maximum viability of the organism was observed in press mud based biofertilizer because it was a rich source of nutrients especially carbon which favours the microorganisms survivability, compared to vermicompost, then lignite and was lowest in cocopeat.

Hema et al. (2012) studied the influence of microbial enrichment on microbial population and nutrient status of organic manures. Microbial population in the slurry before enrichment was $80.5 \times 10^{5}$ bacteria, $124 \times 10^{3}$ fungi, $12 \times 10^{2}$ actinomycetes, $15.3 \times 10^{3}$ phosphate solubilise micro organisms and $20.2 \times 10^{3}$ free living nitrogen fixers.

Karmegam et al. (2012) conducted research on the enrichment of biogas slurry vermicompost with Azotobacter chroococcum and Bacillus megatherium. The inoculum level of Azotobacter chroococcum and Bacillus megatherium at rate of $35 \mathrm{ml}$ per $175 \mathrm{~g}$ of vermibed substrate is sufficient to maintain $1 \times 10^{7}$ viable cells up to 160 days after harvesting of vermicompost. The inoculum of biofertilizer organisms in vermibed on $30^{\text {th }}$ day showed 
increased viability rate and hence, the optimized inoculation of $35 \mathrm{ml}$ of inoculum per $175 \mathrm{~g}$ of substrate on $30^{\text {th }}$ day of vermicomposting is helpful for maintenance of sufficient viable population for more than five months in the enriched vermicompost.

In conclusion, the viability appears to be good upto the end of fourth week irrespective of treatments of the biogas manure samples for Rhizobium, Pseudomonas, the viability and Azospirillum. Whereas for Azotobacter the viability appears to be good only upto the end of third week irrespective of treatments of the biogas manures. Finally the viability was significantly more in $T_{5}$ (Cow dung + Fruit waste) for Rhizobium and Azospirillum, whereas in $\mathrm{T}_{3}$ (Cow dung + Kitchen waste) for Pseudomonas and more in $\mathrm{T}_{6}$ (Cow dung alone) for Azotobacter.

\section{References}

Hema, C.R., Sreenivasa, M.N., Hebsur, N.S., Shirnalli, G and Babalad, H.B.
2012. Influence of microbial enrichment on microbial population and nutrient status of organic manures. Karnataka J. Agri. Sci., 25(4): 545-547.

Karmegam, N., Rajasekar, K. 2012. Enrichment of biogas slurry vermicompost with Azotobacter chroococcum and Bacillus megaterium. J. Environ. Sci. Technol., 5(2): 91-108.

Shruthi, H., Krishna, Naik, L., Shivaprakash, M.K., Maina, C.C. 2014. Survivability of Bacillus megatherium in different carrier material for improved shelflife of biofertilizer. National conference on Productivity and Sustainability: Role of Agriculturally Important Microorganisms. University of Agricultural Sciences, GKVK, Banglore.

\section{How to cite this article:}

Kavya, Y., A. Vijaya Gopal, R. Subhash Reddy and M. Sreedhar. 2016. Enrichment of Biogas Manures with Beneficial Microorganisms. Int.J.Curr.Microbiol.App.Sci. 5(7): 242-252. doi: http://dx.doi.org/10.20546/ijcmas.2016.507.025 